\title{
エイズ患者のQOL
}

\section{Nurse's Approach to the QOL of People with AIDS}

\author{
シンポジスト (発表順) \\ 和 泉 成 子(虎の門病院) \\ (Izumi Shigeko) \\ 柴 野 恭 子(東京都立駒込病院) \\ (Shibano Kyoko) \\ (Abe Keiko) \\ 野々山 末希子 (千葉大学) \\ (Nonoyama Mikiko) \\ 司会: 薄 井 坦 子(千葉大学) \\ (Usui Hiroko)
}

阿 部 恵 子(東京慈恵会医科大学附属病院)

司会：シンポジウム「エイズ患者のQOL」の 視点は，(1)エイズ患者の看護を行うための共有 すべき基本知識を確認し，エイズ患者がどこで も医療・看護を受けられるようにする準備, (2) エイズ看護の経験者から学び, 看護部門として 状況に対応するための人的物的な準備, (3)看護 職者として，患者のQOLを高めるケアを行う ために備えておきたい内容について語り合う， の 3 点です。

このようなシンポジウムを組むためには，シ ンポジストの選定が非常に重要です。今回は幸 いにも，まさにうってつけの方々にお願いでき ました。和泉成子さん, 虎の門病院の看護婦で す。今日はアメリカのホスピスで初めてエイズ 患者の在宅ケアをした時の体験を中心にお話い ただきます。次は柴野恭子さん，東京都立駒込 病院の主任看護婦です。臨床経験二十数年の後, 多くのエイズ患者を看とられ，その体験からご 発言いただきます。次は阿部恵子さん，東京慈 恵会医科大学付属病院婦長です。1988年に入院 したエイズ患者の受持ナースを決め，婦長とし てその看護を支えた体験からご発言いただきま す。進行はまず各シンポジストからご発言いた
だき，追加発言と相互の質疑応答を行った後， 会場との質疑に入りたいと思います。それでは 和泉成子さんから打願いいたします。

\section{私がアメリカで見たもの}

和泉：私がアメリカのあるホスピスで働いてい た時，何人かのエイズ患者もその中に含まれて いました。

エイズ患者のQOLについて考える時, 社会 的な偏見とか感染への恐怖とか不安というのは 見逃せない大きな影響因子であると思います。 特に医療者からの偏見, 差別または無理解が, その患者のQOLを大きく低下させるといらこ とは事実だと思います。ところが多くの医療者 が，疾患あるいは感染者に対して偏見や不安を 持っていることも事実だと思います。そこで， 私が初めて実際にエイズ患者に関わった過程を 振り返りながら，ぞうやってこの点を乗り越光 たかについて括話したいと思います。

最初にエイズ患者をケアしたのは，在宅訪問 を中心に行っているホスピスでナースエイドと して働いていた時でした。スケジュール係から いつものように電話で, 患者がケアを必要とし 
ている日時が伝えられ，行けるかどらか聞かれ， 私が行かれると答えたので患者の情報が与えら れました。

患者は，38歳男性，エイズによる体力低下の ため日常生活に援助が必要, 妻は仕事をもって おり日中の患者への介護者を必要としている, といらのがその情報です。行くと言ってしまっ たこの時点でエイズだといら診断名を聞かされ たわけですが，エイズ患者だから訪問を拒否し ようとは思いませんでした。

エイズといら診断名はホスピスの中でも学校 の授業の中でもよく出ていたので，特に驚きは ありませんでしたし，勤務先のホスピス内の患 者の約 $20 \%$ がエイズ患者でしたから，ショック とかパニックはありませんでした。しかし，ぞ んな病気でもよく知らない病気の患者をケアす るといらのは不安なものです。特に在宅ケアで はその患者の家にいる医療者は私 1 人というこ とになりますので，不安や疑問があればよいケ アはできませんそこで私は自分のスパーバイ ザーにエイズ患者を受け持つのは初めてである ことを話しました。

彼女はホスピスのオリエンテーションの時に 配られた紙を取り出して来て, 感染予防のため の決まり事を私に再確認しました。これはユニ バーサル・プリコーションとアメリカで呼ばれ ているガイドラインで, あらゆる種類の体液を 媒介とする感染を予防するために作られ，全米 の医療施設で注涪通に適用されているもので 寸。

この確認をした後に，スーパーバイザーは非 常に一般的な助言をしました。ユニバーサル・ プリコーションに基づいた物品を携帯すること, 患者の守秘義務などで，これはエイズ患者に限 らずどんな患者のところに行く時にも口をすっ ぱくして注意され続けてきたことです。

こうして私はいつも通りの使い捨て手袋を持っ て患者を訪問しました。彼は開放創もなく，激 しい咳もしておらず，下痢は頻回でしたが援助 さえすればトイレまで歩行することもできまし た。末期のエイズ患者によく見られる著明なる い瘦を示していましたが，自宅で自分のベッド に横になり猫を相手に話をしたり，仕事に行く
奥さんにキスをしたりするところを見ていると， 私が今まで看てきた患者と何の違いもありませ んでした。実際に行ったケアもホスピス内の多 数をしめていた癌患者に行ったことと同様で, 全身清拭も陰部以外は手袋なしで行いました。 この時点で, 私の中でエイズという疾患は種々 ある疾患の 1 つでしかなくなったのだと思いま す。

エイズ患者の看護といらものは特別なもので はありませんでした。以上の過程は私の中で非 常にスムーズに経過したため, 今回改めて振り 返ってみるまで特に意識したことはありません でした。逆に日本に戻ってきた時に，何人かの 医療者がエイズ患者への対応を特別なものとし てとらえているのを見て異様な感じがしました。 しかし，現在の日本では，まだまだエイズとい ら疾患名に対して, 冷静に対応しにくい状況で あることがしだいに分かってきました。

そこで，なぜ私がエイズ患者のケアにすんな り入っていくことができたかの理由を考えてみ ました。まず，ユニバーサル・プリコーション の存在だと思います。こちらはすべての患者の 体液, つ屯り口腔分泌物, 血液, 便, 尿, 創, そしてすべての浸出液を感染源として分離して います。このユニバーサル・プリコーションは B型肝炎を中心とする血液性感染疾患の予防対 策として防疫センター (CDC)が提唱したバリ ア・テクニックです。そして，1988年にHIVの 感染予防も考慮して改訂されたものです。全米 の約 62 万の施設とその他の血液, 体液に触れる 可能性の考えられる職種の約70万人によって履 行されていると言われています。

これは非常にシンプルなルールで，これに基 きますと, 患者あるいはクライアントが, キャ リアまたは発症者であるか否かに関わらず, 全 ての人の全ての体液は感染の可能性があるとし て扱われ, 体液に触れる可能性がある時は, 必 ず適切な防御物品, すなわち使い捨て手袋，工 プロン，マスク，ゴーグルなどを使用し，それ らはほとんどの医療機関で提供されています。

全ての患者に接する時にこらいら物を使らと いらのは少し大げさといら感じがあるかもしれ ませんが，それはその患者の状況あるいはどう 
いら体液に接する可能性があるかによって, 看 護婦もしくは介助者, 医療者が判断して使用し ます。

1 度使用した注射器は 2 度使用せず, 使用し た針には再びキャップをしてはなりません。こ れは針刺し事故を予防するためです。再びキャッ プをしなくてすむように，ナースステーション にはもちろん, 各病室に針あるいは污染した鋭 利な物を捨てるための容器が設置されています。

例えばベッドサイドで注射をすると，患者の ベッド脇にその容器が置いてあり, 使用された 注射器はそのままその容器の中に捨てられます。 私が働いていたホスピスで使っていた容器は， 郵便受けのような形をしていて 1 度捨てた針や 刃物は取り出せないようになっています。そし て，各処置の間に必ず流水による手洗いを行う といらことです。

医師や看護婦のみならず, 医療施設内で働く 全ての人達, エイドや清掃の職員, リネンのラ ンドリーをする人達も, 就職時に同様のオリエ ンテーションを受けて説明され, 全員によって 履行されています。これに基づいて医療を行っ ていると, 誰がどのような感染をしているかを 神経をすり減らしながら覚えている必要はなく, この人はこういらふらに感染しているから血液 のついた物は区別しなきゃいけないといった心 配をすることはまずありません。また，検査で 感染が陰性と出ていてもその後陽転したのでは ないかというような不安を感じることもありま せん。つまり，かなり安心した環境で仕事がで きます。

また, 全ての対象を感染の可能性があるとし て扱らために, 感染者が差別されるといらこと も避けられます。このように種々の感染に対し て, 単純にしてかなり確実な感染予防の環境が 整っていたことに加えて，HIVがどのような経 路で感染するかが明らかになっており, 職務中 に感染しうる経路はユニバーサル・プリコーショ ンを正確に履行することによって断つことがで きるとわかっていたので, 感染に対する不安が なかったと思います。

そして，アメリカではエイズの症例が多数あ るために，医療者や社会の中でそれを受け入れ
るノウハウが普及しつつあるといら土壤が，私 の個人的な受け入れを容易にしたのだと思いま す。施設内での管理者, 指導者, 同僚達がHIV 感染とかエイズに慣れていて, よく勉強, 理解 していたために自然に適切なアドバイスをもら え指導してもらえたのだと思います。疑問や不 安があれば，いつでもエイズ患者をケアした経 験のある相手に相談することができむした。

彼女達にとって, エイズは疾患の 1 つでしか なくて，そらいった雲囲気が私にもらつったの だと思います。社会的にもエイズ発見当初の混 乱は拈さまって，今度は感染者が増えてきたこ とから感染者を受け入れざるを得なくなって, 社会的な教育あるいは理解が進んできたのだと 思います。

別な見方をすると，人々がエイズもしくはHIV という言葉に慣れつつあるのだと思います。こ のような環境の中にあって，私はエイズ患者の 看護にすんなり入っていくことができたと思っ ています。正しい知識とそれに基づいた安全な 労働環境があれば，エイズ患者のケアは恐ろし いものでも危険なものでもありません。

その後私は, $\mathrm{RN}$ とら看護婦の資格を取っ て, 同じホスピスの中で引き続き看護婦として 何人かのエイズ患者をケアしました。今度はエ イズ患者が抱える様々な看護問題に直面するこ とになりました。それらは, 疼痛や感染症など の身体的問題であったり, 社会や家族からの偏 見や差別による孤立などの社会的問題, あるい は死を受け入れる過程の苦しみであったりしま した。その時に患者を疾患名ではなく， 1 人の 人間としてとらえることができたのは，以上の ような経過でエイズ患者に対する色めがねを持 たなかったからではないかと思っています。

非常に個人的な経験ではありますが，私が看 護婦としてエイズ患者に入っていくことを容易 にさせたこれらの状況は, 日本の看護婦達がエ イズ患者の看護に入っていくことも容易にさせ 得るのではないかと思っています。患者を色め がねなしに見ることがでさた時に，初めて患者 のニーズをフェアにとらえることができ, QOL を高める看護を検討することが可能になるので はないでしょらか。以上です。 
司会：ただ今のご発表は，エイズ患者の爆発を 見たアメリカでの体験です。日本ではどのよう なプロセスを経て現在があるのか，柴野さんに お願いいたします。

\section{ロ日本の場合は…... 今日までのプロセス}

柴野: 私は昨年の 7 月から駒込病院の感染症科 で50名近いエイズ患者の看護をしてきました。 エイズ看護の経験は 1 年しかありません。不十 分かと思いますが，私が経験したことを中心に お話をさせていただきます。

最初に駒込病院のエイズ看護の歴史をさっと 振り返ってみたいと思います。駒込病院でエイ ズの診療を始めたのは1985年で, 今年の 8 月ま でに126名の患者が入院治療を受けすでに63名 の方が死亡されました。

85年に診療を開始した当初は, 感染防止と患 者のプライバシ一の保護というのが看護の目標 でした。患者は全員個室で隔離に近い状態でケ アがされていました。

当時看護をしていた人達が自分達の看護姿勢 を振り返って，エイズ患者に対する偏見や感染 の不安が強いのが問題だと率直に述べていまし た。看護婦が偏見や先入観を持ってはいけない ことはよくわかっているが, 簡単に克服するこ とができないと，記録に残っています。

126名の患者の感染経路をみますと，99名が 性交渉，27名が血液製剂での感染です。性交渉 で感染された方が多かったとか，あるいは85年 当初はホモセクシュアルの方が多いという駒込 特有のことが影響しているのだと思います。感 染経路の違いで患者を区別してはいけないとい うことは言うまでもないことですが，現実には 看護婦も決してそらした偏見と無縁ではなかっ たということです。看護婦ですから, 当然感染 者の苦しみもわかるし, さりとて自分達が感染 することの恐怖も強いという両者の間で非常に 苦悩している看護婦の率直な意見が残されてい ます。

その後, 90年には感染者の増加もあり, 個室 でケアをすることが物理的にも困難となって大 部屋での対応に変わっています。安静度も院内
はフリーになっています。

昨年私が配属された時点でも，例えば血圧計 とか尿器とかいくつかの看護用具が感染者と他 の患者と別であったり，浴室も別というような 必要以上の防御体制が一部残っていました。し かし，今はかなり解決されましたし，看護婦の 感染に対する不安も「針事故を防げば感染はほ ぼない」といら意識にまで変わってきています。 以上のような経過を経て，今年 7 月には，感 染防止や患者のプライバシーの保護といらのは 看護の目標ではなくて看護の原則ではないかと いらことで, 私達はエイズ看護の目標を次の 2 点としました。

1 つは「HIV感染者自身がHIV感染症につい て正しい知識を身につけてセルフコントロール がでさる」，も51つは「残された人生の送り 方を感染者自身が自己決定できてQOLを高め ることがでさる」といら $2 つ の$ 目標を揭げて今 ケアを行っていをす。

この 2 つ目標を達成するために実際にどう いう看護をしているかといらことを述べてみた いと思います。

まずセルフケアのコントロールができるため の援助ですが, 患者自身がHIV感染症を直視し て正しく理解することは, 次の 3 つの点で大切 です。(1)感染から発症の期間は 5 年から 10 年と 言われこの期間を延ばすため，(2)患者の残され た生活のQOLを高める, (3)他の方感染を防 止するといら意味でも非常に重要な課題です。

性交渉による感染者のなかには, 後悔とか卑 下されている方もいらっしゃいます。エイズと いう病気についても触れたくないとか避けて通 りたいというような姿勢も見受けられ，なかな か指導ができないといらことがありました。

アメリカで使われているセルフケアのハンド ブックを日本の社会や文化や風習に合らよう作 り直しました。このハンドブックは, 患者とエ イズを話題にして話すきっかけを作る上で非常 に大きな役割を果たしていると思います。

セルフケアに向けての指導の重点は, 患者が HIV感染症をひとつの慢性疾患として正しく理 解するといらことです。ハンドブックを作成後, 数例で使用してみた結果, セルフケアの指導は, 
開始する時期が非常に大切だといらことがわか りました。

実は入院されている患者は，すでにエイズが 発症している方が姫とんどで，ターミナルステー ジの方多いのです。

私達がパンフレットを持って行ってエイズに ついて一緒に勉強したり，これからどらいらこ とを気をつけないといけないかお話したいと話 しましたところ，「僕にはもら時間がないし， そんなものは必要ない」と意思表示された方が ありました。実際には入院している方にはあま り必要でないということもわかりました。

ですから私達は感染の比較的早い時期から指 導を開始したいと考㝋ています。病棟の看護婦 が外来で指導できる体制をつくりたいと模索中 です。外来の中で今後指導を具体化していきた いと思っております。

次に，患者の残された生活のQOLを高める ための援助です。残された生活のQOLを高め る上で最大の障害は, やはり周囲や社会の差別 や偏見です。多くの患者が病名はおろかその方 がおかれている状況すら，身近な人にさえ話せ ないといらことがあります。

昨年 7 月から今年の 6 月までに入院された患 者39名が，自分以外の人に病名を告げた状況を 調べをした。誰にも告げていない方が 5 名， 1 人から 4 人の家族とか身近な人だけに話をした 方が 26 名， 5 人以上の方に話をした方が 8 名で, 80\%の患者がごく身近な家族や友人にしか病名 が話せないという状況です。

患者に聞きますと, 今は誰の助けもなく生活 ができるとか，家族に心配をかけたくないから 言えないといらことです。病名を人に告げると いらことは患者の意志で決定されることですが, その方の周りにその患者を助けてくれる人がい るかいないかといらことは，その方の残された QOLを高める上で非常に重要です。

周りに支えてくれる人がある人とない人では 大きな差が出てきています。私達は動けなくなっ てからではなくて，できるだけ早い時期に，家 族や友人に力を貸してもらえる人をつくった方 がいいと話しています。

実際にQOLがどのように違らかを，支える
人のあった例でご紹介します。

38 歳独身の男性で, 家族は拈母さんと 2 人で す。お母さんは地方に住んでいて, この方は東 京で 1 人で暮らしていました。感染経路は言い たくないといらことで不明でした。1979年から 91年にかけてイギリス, アメリカに仕事で滞在 されています。

入院された時にはCD 4 が59で,すでにエイ ズが発症し, 全身にカポジ肉腫ができている状 態でした。入院直後に喉頭のカポジ肉腫による 気道の閉塞があり意識不明に陥りました。家族 に病名を言らかどらかは患者の意向を聞いてか らにしているんですが，この方の場合には入院 直後に意識がなくなりましたので, 地方のお母 さんに来ていただいてドクターからエイズであ ると告知しています。

その後, 副腎皮質ホルモンの大量投与などで 喉頭の浮腫が軽減して奇蹟的によくなられまし たが，お母さんの希望で，この方がエイズであ ることを母親は知らないといらことで亡くなら れるまで通しています。腸管のカポジ肉腫から タンパクの漏出があり, アルブミンの点滴静注, 放射線療法などが行われましたが，今年の 2 月 から髄膜炎を併発して全身衰弱が徐々に進行し, 8 月には死亡されました。

この方は課長に昇任直後の入院で, 最後まで 職場復帰を強く望んでいました。10か月の入院 期間中に故郷のお母さんのもとへ 3 回外泊, 都 内のアパートへの外泊, 買い物や食事, 音楽会 や映画にも友達と頻回に出かけていました。

ここでは最期の 2 週間の様子をご紹介します。

実は駒込病院では今年駒込ナーシングシステ ムといらプライマリーナーシングの看護体制を 導入していまして，私の病棟でも 8 月からこの 看護体制でケアしています。

私がこの方のプライマリーナースになりまし た。私が受け持った時には，低タンパクによる 全身の浮腫と全身衰弱で起き上がることもでき ない状態でした。8月 9 日は彼の誕生日で, 郷 里に帰って誕生日を迎えたいということでした が，外泊できる状態ではなく，お母さんが急い で上京されました。

このお母さんは非常に理性的でしっかりした 
方で，彼をご覧になって，すぐどらいう状態か を理解されたよらでした。私は，お母さんが彼 にどらいら最期を送らせてあげたいのか，私達 看護婦にご希望があるかどうかを聞きました。

「後になってあれもしてやりたかった，これ もしてやりたかったと思い残すことがないよう， できることは全部してやりたい」といら技返事 でした。

亡くなられるまでの 2 週間, 70歳をこされた お母さんがずっと, 病室で付き添われました。 私は「できるだけ苦痛を少なく，母親，友人と 十分別れができる」いう看護目標をあげて看護 に当りました。清拭とか口腔ケア, 食事介助な ど日常のケアは全てお母さんと一緒に行いまし た。

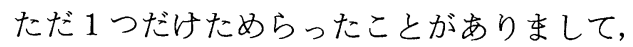
それは陰部洗浄で, 彼の陰部にはカポジ肉腫が できていて，それが崩れて私達看護婦が見ても ギョッとするような状態だったのです。一緒に やっていただくかどうか非常に迷ったんですが, お母さんにそらいら状態ですけれども，どらで しょらかと尋ねてみました。

「もし息子がいいと言うんだったら私は一緒 にやりたい」と。本人にも聞きましたら「おふ くろがそういうふらに言うんだったらいい」と いらことで，一緒にやっていただきました。

その後抢母さんは, 「正直言って非常にびっ くりした, 息子の陰部を小学生の高学年の頃か ら見たことがなくて，しかもあの状態の陰部を 見て非常にびっくりした。しかし，それをあの 子も母親に見せたことによって，私に対して虚 勢をはることもなくなってすごく楽になったの ではないかと思う」と言って下さいました。

最期まで意識もはっきりして, 本当に苦しかっ たと思らんですけれども「大丈夫，大丈夫」と いら言葉を残して亡くなられました。

亡くなられた日に，私はお母さんと霊安室で お話をしました。私はお母さんより先に逝って しまう彼に，お母さんに何か一言残してほしい， お母さんには自分の口からエイズだと言ら機会 をもてればと思っていたといらことを話しまし た。

お母さんからは「あの子はそんなことを言え
る子ではない。しかしそんなことを言える子で はないけれども，私はあの子が何を考えていた かはとてもよくわかっているし，あの子も私の 気持はとてもよくわかっていたと思う」とおっ しゃいました。

そしてお母さんは，「今 2 つのことが私の心 の中に引っ掛かっている, その 1 つは, 彼の性 器に何か欠陥があったんじゃないか, 彼のとこ ろには男性の友人の面会がたくさんあったので 彼がホモセクシュアルではないかと。もう1つ は, 自分は彼の父親と不倫の恋愛の末に結婚し たということで，その報いが彼にきたのではな いか，もしそらだとしたら，彼にあまりにもす まない」と自分を非常に責めていらっしゃいま した。

私は次のように答えました。彼には身体的な 欠陷はもちろんなかったし，予母さんの恋愛に ついては「僕の拈母さんは大恋愛の末に結ばれ たんだ，非常に情熱的な人で，だから僕に対し ても誰でもいいから結婚しろっていらふらなこ とは 1 度も言ったことがなくて，それはすごく 助かっているんだ」と，抒母さんのことは誇り に思っていらっしゃいましたと伝えました。

お母さんは，そんなことを言っていましたか と感慨深げでした。1 カ月を過ぎた頃に手紙を いただきました。夜中に目が覚めると最期の病 室での風景が浮かんで来て, 気がつくと大丈夫, 大丈夫という，息子がいつも口癖にしていたそ の言葉を繰り返しながら私は生きていますと。

私が残して欲しいと思ったメッセージではあ りませんでしたが，彼はしっかりお母さんにメッ セージを残して亡くなったわけです。

エイズ患者は彼のように恵まれた方ばかりで はなくて，身寄りのない方や天涯孤独の方も少 なくありません。

一人一人の患者のQOLを高めるために, 医 師, 看護婦, MSW, 心理療法士, 精神科医に よるカンファレンスをもっています。外国では マネージメントをする専門職がいるそうですが, 日本にはいません。現状では十分とは言えませ んが，その役割を看護婦が果たしつつあります。

最後に, 私達は日常のケアの中で患者の人格 やQOLを大切にすると同時に, 社会的な発言 
をしていくことも大事だと思います。

エイズは 20 世紀後半を生きた私達にとって, 現状では治癒を望めない困難な病気ですし，19 世紀のペストやもっと前のらいや，国民病と言 われた戦前の結核のような特別の病気だと思い ます。そういう意味では看護職として国民の健 康を守り増進する役割を果たす私達が, 社会的 にも発言していくことが非常に大事ではないか と思います。

この秋, HIV看護に携わる人達のネットワー クをつくりました。このことは追加発言の時に 発言させていただきます。

司会：今日に至るまでの歴史を㥂話し下さいま して，日本も急速にHIV対策が進んできたとい ら印象を持たれたかもしれません。では，その 出発の頃に大変苦労された阿部婦長さんからお 話いただきましょう。もら一度, 歴史の流れを 追らつもりでお聞きください。

\section{口婦長の立場から， \\ エイズ患者を受け入れて}

阿部 : 私達は 5 年前, エイズでターミナル期の 患者 $\mathrm{A}$ 氏の看護を経験しました。

当院に拈いては 2 例目か 3 例目であったよう に思います。A 氏は44歳の男性で，その 1 年前 に舌の潰瘍で入院した時, エイズの診断を受け ていました。自分の店をもつ計画で蓄えは十分 にあり，診断を受けてからは働いていた店をや め，家の中に閉じ込もりがちな生活をしていた ということです。そして 1 年後, 下痢と発熱で 衰弱し内科病棟の個室に入院されました。

外来の主治医には「ここが死に場所」と言い, 死を覚悟しての入院だったのです。私はその病 棟の婦長で, 3 つの病棟と教育を担当しており, 日常直接患者さんに接することは稀で, 間接的 な関わりによってより良い看護が実践されるこ とを目指していました。プライマリーナーシン グを取り入れていましたので, 主任とも相談し てA氏の担当は看護婦歴 7 年の $\mathrm{B}$ と新人のペア に決めました。

亡くなるまでの 1 力月, 看護実践は試行錯誤 で, 私はA氏や看護婦達が気になり, 主任から 様子を聞いたり，看護日誌にコメントを入れた
りしました。この看護から学んだことは，5年 を経た今でも看護婦を育てる力になっています。 その看護の実際と学んだことを述べたいと思い ます。

B は初め, 感染予防対策に動きました。入院 時の計画には, 病室をどこよりも居心地の良い 場所に，とあるにも拘わらず，翌日は食器，下 着, シーツ, 消毒はどうするのか, ゴミは？と 封じ込め作戦が飛び交っています。掃除の人か らは, 食器まで捨てるような恐い感染症の人の ゴミは扱いたくないと言われてしまら状態でし た。

私はそこまでの必要はない, 今まで外で食事 もし, 電車にも乗り, 普通に生活してきている のだから，と言らもののその根拠を十分に説明 でさない歯がゆさを感じました。実際に触れる のはあなたではない, 私達ですとみんなが言っ ているようにも思いました。そして翌日の日誌 を見てみると「廊下に出てきてしまら」と書か れていました。

これでは今まで以上に規制の強い辛い生活に なってしまう，何とかしなければと思い看護日 誌にコメントを入れました。「人間にとっての 免疫の仕組みを考えてケアの方法を考㝋よう。 彼の外部環境が敵になってしまう危険性が大き いですね，私達が感染源を運ばないようにした いものです。熱と肚門痛に対しての細やかなケ アが孤独感に対するケアにつながるね」と書き 入れました。

そして主任には，大島清著『世紀末の病』を 提供し, 勉強会を提案しました。2,3 日で看 護婦の言動も日誌の内容も変わりました。激し い咳嗽, 誘発する嘔吐, 発熱, 下痢, 肛門の痛 みなどの苦痛の状態だけでなく, 細やかなケア の方法, リンパ球の数值, 下痢を止められない 理由などが書かれ，「Aさんは優しい人なんで す, シュースの缶を膿盈の代わりにしたり, 辛 いのに便器を使わず，いつもすまなそうに，手 を洗ってね，気をつけてねって言らんです」と いら言葉も聞かれるようになりました。

2 週間した頃，Bの記録が目にとまりました。 遅くまで残っていた夜, A氏に呼ばれて部屋に 言った時の会話です。下痢が続いていると訴え， 
トイレの近くでイスに座るA氏に「辛いですね」 と枕を添える。患者「これからが本当に辛いん だよね。今夜も眠れないよ。この病気でここで 死んだ人いるって聞いたけど，その人のこと教 えてよ」，B「私はそらいら患者さんがいるっ てことは知らないです。どうしてですか」「う ん, この病気で最期はどんなららになるのかな あと思って。看護婦さん達も勉強会とかして, 知ってることも多いんでしょう」「勉強会はし ているけど，全てのことが全ての人に当てはま るわけではないし」「僕は免疫力が弱くなって こんなふらになっているんでしょう, 免疫力が 強くなることはないからこのままどんどん悪く なっていくだけでしょら，だったら楽になりた いよ」「楽になりたいってことは？」「もう死に たいんだよ」と。

私はこの記録を読んで，Bの関わりは A氏の 心を表現するのを助けている。看護は良い方向 に進んでいると安堵しました。

そして気がかりなことは, 深夜で21回の下痢 があるという情報でした。A氏の生命には危機 が迫っていることが読み取れたからです。

A 氏は両親はすでになく 12 人兄弟の 11 番目, 独身です。兄弟とは疎遠で弟に下痢で入院する と伝えただけで，兄弟の家族に迷惑がかかるこ とを心配してその後連絡をとっていませんでし た。

その一方，「がんばって何かあるならがんば るけど，家族がいるわけじゃない自分一人」と 孤独を訴えるA氏でした。

私はこのまま一人で死をむかえてよいのだろ らか，それはまるで猫の死であって人間として の死ではないように思う，それに兄弟には彼の 死をどのように説明するのか，下痢で死亡，そ れとも実はエイズで?，いずれにしても兄弟が 動摇することには変わりがないのではないかと 主任に投げかけました。

翌日，主治医がA氏に弟に連絡をとることを 勧めたようです。

2，3日して弟夫婦が来棟しました。A氏は 自ら重症の下痢と脱水と説明し，もし自分に何 かあっても医師を恨まないで欲しいとそえたそ らです。医師からは抗生剤の効かない下痢, 便
からは大腸菌しか検出されない，菌が見つから ないとも言えると説明されました。

その数日後には兄弟が病名を知りたいと希望 し，A氏の気持ちを尊重して，知らないふりを 通すことを約束して病名が告げられました。

やはりそうですかと動摇もなく，一人で苦し んでいたのですね，とそれからは毎日面会に来 るようになりました。

私は病名を告げたのが間違っていなかったと， 医師や看護婦の対応が兄弟の動摇を最小にした ことを確信し，これでよしと安心しました。

ところが少しして，朝のカンファレンスで $\mathrm{B}$ がAさんのことで困っていると話し始めました。 A 氏は寝返りもできないくらいなのに，兄弟が 来ると気をつかって力を振りしぼる，兄弟は出 来るだけの事をしてあげたいと毎日面会に来る。 このままでは A氏は消耗するばかり，どちらを 立てれば良いかと言うのでした。

私は 8 時45分には患者の前に立てるようにと いう病棟のルールを大幅に破っていることも気 になりながら，みんなを見ると，黙ってらつ向 くだけです。沈黙に我慢できず「今ここで話し てもしょらがない，受持が判断できないよらな ことをみんな答えられない。さあ 9 時, 急いで 患者さんのところへ行って」と打ち切りました。

この時のことをBは鬼よりひどい婦長だと思っ たそらです。私は何も解決していないBが A 氏 の部屋にどらいら気持ちで行くのか心配です。 ゆっくり話を聞かなければと思い，すぐ別室に 呼びました。

思った通り，怒ったように無表情に入ってく るBに，何に困っているのか整理してみようと 投げかけをした。Bが，A氏の体は命がいつ途 絶えてもおかしくない状態で, 幻覚もあり黒人 や白人がのしかかってきて，それを必死に振り 払い，エイズのお前なんか死ねという声とも闘っ ているんです，と説明するのを聞きながら，私 は忤やんでも悔やんでも取り返しがつかないこ とだしね。死んでしまいたいと思うのも当然だ ね。でもそれもできない。自殺の報道は兄弟達 を苦しめる。どんなに辛くても生きていかなけ ればならない。どうしてこんな目に合うのかし らね，と言葉をはさみ，Bは「そうなんです」 
と強くうなずき，だからいっそ死んだ方が楽に なると言わんばかりです。

看護の方向性が見えなくなったのは，こんな 状態でも生さていなければならないのかという 迷いであり，A氏の死にたいといら言葉に答が 見つからないのだろらと思いました。

$\mathrm{B}$ 考学が変わるには，エイズの $\mathrm{A}$ 氏は世の 中の迷惑な存在，といら見方を乗り越光る考兄 方が必要ではと思い「若くて，明るくて，元気 で，役に立つのが世の中の素晴らしい存在？」 などと話しながら机の上を見ると，重心児の看 護を特集した「精一杯の命に向き合う」といら 雑誌が目にとまりました。

小児看護を 5 年間経験しているB B゙障害児を 見ていないはずはありません。喜ばれない状態 での誕生もみているはずと思いながら，優しい 眼差しで障害児を抱く写真のページをひろげま

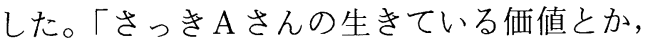
世の中の迷惑とか言ってた亦，そうするとこの 子達は生まれた時からその迷惑を背負い込んで 世の中に存在していることになるね。今まで見 てきたこういら子どもの拈母さんはこんな子死 んでしまえばいいと思って育てる？この子が 話せるとしたら，生さててごめんねって言うの かしら」と問いかけました。

「そんなことありません」ときっぱり答える Bは，もら十分わかったといら顔つきでした。 この時のことを Bは，あっやられた！といら衝 撃的なイメージで，A氏の命をどら考光ている のかを問い正されたような気がする，それから の私は病室に向からことも苦痛ではなくなり, 残された時間を 1 分 1 秒むだにはでさないと思 うようになった，幻覚に苦しむA氏を現実に引 き戻し，心地よいと感じる快の刺激をできるだ け多く与えることが看護婦として私のできる精 一杯のことになったと言います。

それから $2 ， 3$ 日して，寝返りもできずオム ツを使うほどのA氏がエレベーターの前に立っ ているのをBが見つけました。「7階に行って

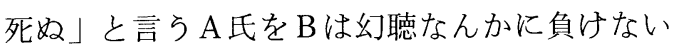
ぞと，しっかり抱きかかえて部屋に連れもどし たそらです。

その時のプロセスレコードが表 1 です。この
言葉の後，A氏は眠るように意識がなくなり， 2 日後, 兄弟達が見守る中で亡くなりました。 エイズに対する社会の反応は，自分は迷惑な 存在といら A 氏の認識をつくりました。生きて いる意味がない，価值がない，そればかりか生

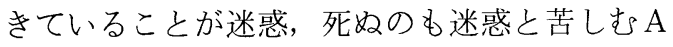
氏でした。

Bの，かけがえのない大切な存在であるとい ら表現によって，A氏は「生さる，生さられる だけ」と自分の存在を肯定してその苦悩を乗り 越え, 安定した状態で残り少ない命を生きたの だと思います。

またBは，A氏の看護を振り返り，それまで に経験したことのない辛さを感じたが，A 氏の 死をみとりながら何故か充実感を覚えたと表現 しています。Bは仕事に行き詰まり，小児科か ら配置転換したばかりだったのですが，A氏の 看護を通してその壁を乗り越えたと言えるでしょ ら。

私はこの事例を通して，他の生物にはない人 間だけが持つ力を実感しました。それは自分の 置かれている苦境を乗り越光る人間の頭であり, それを支觉るのもまた人間の力であるといらこ とです。そして学んだことは立場の変換という ことです。

ナイチンゲールは，看護婦に自分自身は決し て感じたことのない他人の感情の中へ自己を投 入する能力を基本として求めています。私は相 手の立場に立つことのできる看護婦を育てたい と考㝋ていました。

しかしそれでは十分ではなく，相手の立場に 立つのは，看護婦として何をすればよいのかを 見い出すためといらことが明確になりました。 それは看護も教育も共通で, 私ではないその人 は, その人の感情や考光, 意志を持っている, それでいながら援助を必要としているといら根 本矛盾に対する課題です。

初めに看護婦が $\mathrm{A}$ 氏の封じ込めを考学てしまっ たのは，感染源の正体がつかめず感染経路も不 明確だったためでしょう。そして患者の力を弱 くさせるような看護になってしまいすした。こ こでは全く相手の位置に入れていません。看護 婦が病気の性質を知り，相手に対する関心が高 
表 1 A 氏と B 看護婦のプロセスレコード

\begin{tabular}{|c|c|c|}
\hline 対象の言動・状況 & 看護婦はどう思ったか & 看護婦はどう行動したか \\
\hline & $\begin{array}{l}\text { (1)エイズに対する一般の(私も } \\
\text { 含めて)認識がこんなにこの人 } \\
\text { を苦しめていたのかなあ。 }\end{array}$ & $\begin{array}{l}\text { (2)「どうしても死にたいの? } \\
\text { 患者をベッドに横にしたあと話 } \\
\text { しかける。 }\end{array}$ \\
\hline $\begin{array}{l}\text { (3)「だって怖いんだもの。7 階 } \\
\text { に行って死ねって言うんだ。そ } \\
\text { の方が楽になるし」。 }\end{array}$ & $\begin{array}{l}\text { (4)この間, ドクターが “飛び降 } \\
\text { クたら血が出るよ”と言った時, } \\
\text { 正気になったっけ。 }\end{array}$ & $\begin{array}{l}\text { (5)「Aさん，人の迷惑になるこ } \\
\text { とはいやだって言い屯したよね」 }\end{array}$ \\
\hline 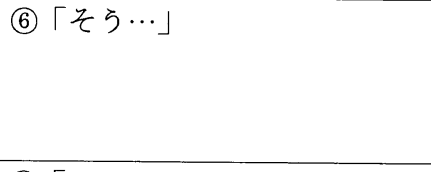 & $\begin{array}{l}\text { (7)心の優しいAさんだから, 私 } \\
\text { たちの今の思いを伝えたら通じ } \\
\text { るかもしれない。 }\end{array}$ & 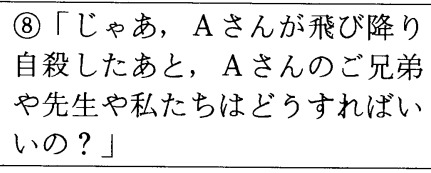 \\
\hline $\begin{array}{l}\text { (9)「えっ? みんな本当に僕の } \\
\text { こと考えてくれているの? W } \\
\text { つ屯で一緒にいてくれるの? }\end{array}$ & $\begin{array}{l}\text { (10よかった。思いが通じたみた } \\
\text { いだった。 }\end{array}$ & (11)「Aさんが退院するまで」 \\
\hline (12)「長くなったら…? & $\begin{array}{l}\text { 13)死が近づいていることは, A } \\
\text { さん自身が一番知っているはず } \\
\text { だ。ずっといと言ったらウソに } \\
\text { なるな。今のAさんにウソはつ } \\
\text { けない。 }\end{array}$ & $\begin{array}{l}\text { (14)「らーん, Aさんとはここで } \\
\text { 働いていたからこそ出会えたし, } \\
\text { それは大切にしたいです。でも, } \\
\text { あんまり長くなってお嫁にいき } \\
\text { そびれたら, Aさんのせいにし } \\
\text { ようかな」 }\end{array}$ \\
\hline $\begin{array}{l}\text { (15)（ニッコリ笑って）「じゃあ } \\
\text { 生きる。生さられるだけ」 }\end{array}$ & $\begin{array}{l}\text { (16)今のたとえはやっぱりおかし } \\
\text { かったかなあ。でも, きっと } \\
\text { さんはこれで部屋を飛び出すこ } \\
\text { とはしないだろらな。Aさんを } \\
\text { 苦しめているものからAさんを } \\
\text { できるだけ守ってあげよう。 }\end{array}$ & 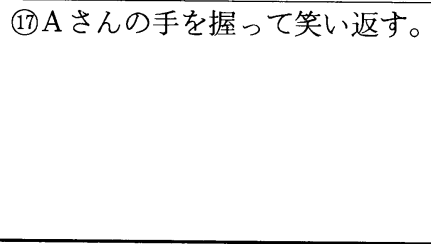 \\
\hline
\end{tabular}

まると，相手の方から看護婦を思いやる言動が でて，両者は近づいていきます。BにはA氏に 呼ばれて訪ねた時の場面で大きな変化が起きて います。

Bは，私が対面していたのはエイズのAさん であった，Aさんその人といらよりエイズ患者 一般を見ているよらな思いで対面していた，と 振り返っています。「この病気で死んだ人のこ とを教えて，最期はどらなるの」と問われた時 には，BはA氏が死のことを考えているとは全 く予想せずに関わっており「楽になりたいんだ よ」と言われて初めて，死にたいなんて言われ たらどらしようと思いながら「楽になりたいっ てことは?」と問い返したのだそらです。A氏 の気持を察して問い返したのではなく，ただわ からないから問い返しただけの会話だったとい らことが，随分後になってわかりました。

Bは「死にたいんだよ」と言われた後のこと を次のように表現しています。その時無言で過
ごした何分かの間に，私は逃げ場のないどん底 に陥ってしまったのかもしれません。

㷌り道, 電車に乗ってふと周囲を見渡すと, 周囲の人が自分とは違ら世界のように感じまし た。家に帰っても電気もつけられず, 電話のべ ルが鳴ってもでる気も起こらないのです。その ような暗い気持ちはその日限りに留まらず， あ たかも自分自身がAさんと化してしまっていく かのようでした。

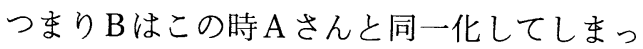
たのです。相手の感情の中に入り，頭の中を読 みとろらといら取り組みではなかったので, 「死にたいんだよ」といら言葉で, 突然 A氏の 内面に入れられたためにパニックになり混乱が 生じたのでしょら。だからその後もずっとA氏 の位置から抜け出ることがでさなかった。そう して同一化したままで進んでしまい看護の方向 性を見失ってしまったのでした。

一方, 間接的に見ている私は, エイズと知っ 
て生きてきた $\mathrm{A}$ 氏は，この 1 年間毎日死と向き 合いながら苦しんできたのだろら，どんなだろ らと想像しながら，みんなの行ら看護を気にし ていました。ですから当然 B は死のことが出て くると予測しながら関わっているものであると 勝手に読みとって，Bの対応は A氏が自分の気 持を表現するのを助けていると判断して安心し ていたのでした。

Bが自分の位置から動かずに A 氏と対応して いるように，私も自分の位置から動かずに，勝 手にBの頭を判断していたことになります。あ わててそれを修正しようとする場面では，Bの 感情や考えているだろらと思われることを想像 しながら表現させ，同時にBの過去の体験とも つなげてどんな刺激を入れれば $\mathrm{B}$ の考光は変わ るかなと考劣ています。

つまり，相手の位置に入りながら指導する立 場で何をすればよいかと両方の立場を行ったり 来たりしていることが分かりました。それは B が A氏の最後の「生さる, 生さられるだけ」と いら考えに変わることができたプロセスレコー ドにも表れていることです。対象の立場と自分 の立場とを行ったり来たりしているといらこと では全く共通でした。この事例からの大さな学 びは，この立場の変換のことです。自分を含め て立場の変換が自由自在に出来る看護婦を育て るのが私の課題となっています。

司会: 本年の 8 月末現在, 日本には601名の工 イズ患者と 2,803 名のHIV感染者がいらっしゃ るそらです。これは報告された例だけです。感 染の問題は基礎的な研究が進むことによって, 和泉さんの発表でおわかりのように私達には乗 り越えられるといら方向性が見えてきたと思い ます。

組織的な対応としては，今日本ではエイズ患 者が安心して医療や看護を受けられないと, 国 際的に大変な非難を受けております。その問題 も, 柴野さんの発表で組織も変わっていくとい らことを実感していただけたと思います。

当初私は，柴野さんを守りながら発表してい ただかなければいけないと思っておりましたが， ここ何か月かの間でこのよらに晴れ晴れとした 顔で発表していただけることになりました。こ
れはエイズ患者が組織を育ててくれたと私達は 受けとめています。

阿部さんのお話を聞いていると，601名の患 者がいれば，それぞれのプライマリーナースが いて育てられる。そしてそのプライマリーナー スを見つめている管理職もまた育てられるとい らことを教えられたと思います。

今 3 人のご発表を拈聞きになって，でもやっ ぱりエイズは恐いのよねといら気持をお持ちの 方もあると思います。看護の仕事には, 手術, 透析, 分婏などどうしても避けられない血液と の濃厚な接触があります。

そこでもらひと方, 野々山未希子さんに追加 発言をいただきます。野々山さんは助産婦とし ての 6 年の経験の中で, HIV陽性の妊婦と関わっ てこられました。現在は千葉大学看護学研究科 博士前期課程に在籍中です。

\section{口 周産期医療の現場では}

野々山：私は某病院産科病棟において数例の $\mathrm{H}$ IV陽性妊婦のケアを経験しました。患者の受 け入れにあたって特に注意したことは, 院内感 染の防止, プライバシーの保護, 精神的援助, そして分婏目的であれば母子間感染の予防です。 その中から私が感じたことを含めて述べさせて いただきたいと思います。

初めに, 院内感染の防止について。医療従事 者へのHIV感染源として, 血液, 腔液, 血液を 含む体液に対して注意しました。1 例目の患者 を受け入れるにあたり, 病院にあったHB感染 マニュアルを元に, HIV感染マニュアルを作成 しました。一般患者と違ら点は, HB専用トイ レを使用し, 使用後は除菌クリーナーで便座を 拭く，血液の付着した污物はビニール袋に入れ 封をした後, HB専用污物入れに捨てる。シャ ワーは最後に使用し $2 \%$ ピューラックス液を流 すなど血液に対する対策があげられます。食器 など血液, 体液による污染のない物は特に区別

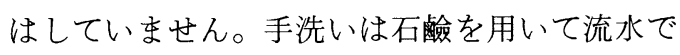
行い, ペーパータオルで拭きウエルパス液をす りこむ。注射などの処置にはゴム手袋を着用す る。血液, 体液の飛散が予想される処置には, 污染の可能性の程度によりゴム手袋, ディスポ 
ガウン，ディスポマスクなどを使用する。特に 分婏, 手術など多量に出血する可能性のある時 は, 直接介助にあたるスタッフは, 眼出し帽, 足袋などを使用し緊急事態に対応できるように する。可能な限りディスポ製品を使用する。血 液などによる污染が予測される物品は全て専用 とし, 退院まで室内から持ち出さない。使用器 具, リネン類の消毒, 污物処理を確実に行らな どがあげられます。医療従事者のHIV污染事故 の大部分は針刺し事故によるものです。私達の ところでも, 針, メス等鋭利なものを扱ら時に は十分注意し，声かけをし合らようにしていま した。またりキャップはしない，使用済みの針 はその場でMDボックスへ捨てるなど針事故の 予防に努めました。その他, アナムネーゼ聴取, 観血的な処置，分娩などは事前に担当者を決め ておくことで落ちついてケアできるようになり ました。

特に分㛌時は, 院内感染を防ぐために, 分婏 係とは別に担当者を決めておき，他の患者と交 互に診察することのないようにしました。産科 は血液や体液に触れる機会が多く感染の危険性 が高いということもあり，他の診療科から見る と過剰とも思觉る防備を行っているかもしれま せん。

しかし現在のところHIV感染に対する予防薬, 治療薬もなく, 血液, 体液に触れる処置を行う 時の過剰な防備はやむを得ないと思われます。 この時, 患者に差別されているといら意識を起 こさせないよう注意します。患者の行動を制限 する時などはよく説明し，必要性を理解しても らうこと, 少しでも快適な入院生活が送れるよ う, 何が必要で何が不必要なのかを知って適切 な援助を行えるようにすることが大切です。

次に, プライバシーの保護について。

HIV感染者の場合, そのことがもれたならば, 今の日本の社会では本人ばかりか家族までが社 会的に差別や偏見を受けることになりか权をせ ん。私達は主に以下のことに注意して看護を行 いました。患者の背景には触れない, 入院中表 札は出さないか患者の希望により仮名を使用す る, HIV感染妊婦が入院することは他言しない, 勤務室内で大きな声で患者についての会話はし
ない，勤務室を離れたら患者についての会話は 一切しない，患者に関する問い合わせには一切 応じず全て担当医師にまわす, 污物にはHIVと は書かずHB十と記入する。そのほか, 分婏後 は出血が多いため感染予防とプライバシーの保 護を考えて個室を使用していました。大部屋に いて一人だけ処置を行ら時にガウンや手袋を使 用したのでは，他の患者が疑いをもつと思われ るためです。また面会者の問題もあり個室を使 用していました。面会者については本人と相談 し, 事前に面会予定者を確認して拈き, 面会者 は最小限度とし, その中でだれがHIV陽性とい らことを知っているのかを把握し, 必要に応じ て室内のディスポ用品に覆いをするなどプライ バシーの保護に注意しました。

しかし表札の出ていない個室から患者が出入 りすることは他の患者の興味をひくこともあり ました。また，医療作業員や委託清掃業者など 病室に出入りする人に対して, 院内感染を防止 しつつ患者への興味や不信感を抱かせないよう にするよらに注意しました。患者のプライバシー を守りつつ，できる限り一般の患者と同じよう な入院生活を送れるようにするためにはどうす ればよいのか今後も考えていかなくてはいけな いと思います。

最後に, 精神的援助について。一般に妊婦は 身体的精神的ストレスを受けやすく, 妊娠や出 産に対する様々な不安を抱いています。さらに HIV陽性であることから自分自身の生命や，胎 児への感染, 周囲に秘密がもれることなどへの 不安や恐怖を感じています。出産するにしろ中 絶するにしろ, 患者は精神的に不安定な状態に あり看護者の援助を必要としていたと思われま す。しかし実際には患者のプライバシーを守る ことに意識が集中し, 精神面の看護が不足して しまいました。患者が秘密にしておきたいこと にふれてしまうのではないかといら不安や, 入 院中だけの関わりであることなどへの遠慮など から，らまくコミュニケーションがとれずに終 わってしまらことが多かったようです。ある患 者からは他の患者との交流がなく看護者の訪室 回数も少なかったため叔しいという声も聞かれ ました。また，私達の説明をよく理解し協力し 
てもらえたものの, 日常生活への制約の多さか らストレスがたまり，些細なことで怒り出して しまった場面もありました。その都度患者の話 を聞き，誠意をもって接することでその場はお さまりましたが，患者がそのような反応を示す 前に私達が気づかなければいけなかったと思い ます。

患者によっては何も訴えずじっと耐えている 人もいます。今思い返してみて，私自身が非常 に戸惑った場面があります。たまたま訪室した ところ，ある患者がベッドに横になり涙を流し ていました。私が患者の側に腰をおろすと，一 瞬こちらを見ましたがそのまま何も言わず静か に涙を流していました。その患者は日本語が片 言で，コミュニケーションのほとんどをジェス チャ一混じりの単語をならべることに頼ってい

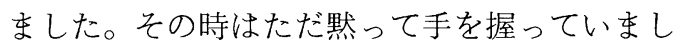
たが，患者の気持ちを聞くどころかどら声かけ してよいのかわからず，側にいるだけで終わっ てしまいました。入院といら特殊な環境の中で のQOLを考光ると, 適切な医療を提供するこ とはもちろん, 確実にプライバシーが守られ, 安心して生活できる場を提供すること，そして 患者が必要とする時に精神的な援助が行えるこ とが重要であると思います。看護者として何が でき, 何をすべきかを知り, 適切な援助を行兄 るように考えたいと思います。

司会：以上でエイズ患者のQOLを考光る上で 必要な最低の事実は共有でさましたでしょらか。 シンポジストの方々に，预い質問をしてい ただければと思います。

柴野 : 阿部婦長さんに。駒込の場合には感染の 恐怖を乗り越えるのにかなりの時を要しました が，この感染者が入院された時には，その辺を 非常に早くクリアされていると思う。そこで大 事な事は何かを教えていただきたい。

阿部：私も実を言らと驚いたくらいでした。 『世紀末の病』を勧めたのは, その本が全体的 にいい本だと思ったからですが，読みなおして みるとHIVの性質がちゃんと書いてあります。

HIVに入る前に, 感染症が発症するのは, 感 染源と経路とその人がその微生物と闘っている
力の 3 つで成り立っているという基本的な押さ えがあります。今臨床では, 結核やMRSAで も感染源と経路にこだわる頭が拭いされないよ らで, 生体側の力をいかに強くするかという面 がまだまだ落ちていると思います。ウイルスと は，宿主に入って初めて生物で，それ以外のと ころでは無生物といら，生物であり無生物であ るといら拈もしろい表現があり，なる汪どと思 いました。そしてそのすみかは T細胞だとわかっ てしまえばなおんだとなると思います。その ウイルスはとても弱いものだと書いてあって, ただ敵は弱いといらだけでなく，忍者小説の中 に出てくる忍者の草のようなもの，とあったこ とが面白かった。敵地に乗り込んで, まるで先 祖代々お宅の家系ですといらような感じで家族 のように入り达んでいて，ある日突然一斉に，

違ら!と言い出すようなイメージがわく本でし た。特に看護婦 B は理解が早かったと思います。 HIVの性質を読み取ったから頭は安定したので はないかと思います。

司会：これで敵が少し見えたかと思います。感 染源と感染経路を問題にする頭でも, ユニバー サル・プリコーションでカバーできますが，そ の根拠をしっかり知っていて相手の頭にイメー ジさせなければ, 全ての人に守っていただくこ と，恐怖心を取り除くことはできない，と聞か せていただきました。

和泉：柴野さんに。HIVもしくはエイズは慢性 疾患として理解するといら言葉にすごく感動し た。患者にこれは 1 つの慢性疾患であるという 教育の仕方はどのようにされているか，具体的 なことを聞かせてほしい。

柴野: セルフケアのハンドブックの 1 番最初に, エイズはどらいら病気かを患者さんにわかるよ うに図入りで書いています。

HIVに感染して発症するまでの期間は人によっ てちがいますが， 5 年から 10 年といわれていま す。非常に長い感染の期間をその人がぞらいう ららに生活するかによって発症の時期が大さく 変わってくることを理解してもららことを中心 にしています。

私達がエイズあるいはHIV感染症を, 感染す る病気ととらえるのと同じように，患者もそう 
いらとらえ方が強い。もちろん人にうつす病気 ですが，長い経過をたどっていく病気で，その 間のセルフコントロールが必要だといらことを まず患者さん自身に理解してもらうというとこ ろを重点に今指導しています。

阿部：追加ですが, 発症してからもそれは言え ると思います。講演会であるドクターが，闘う 力は普段の生活の中にあると言われていました。 発病を遅らせるには, 体力, 気力そして情報交 換だと。

体力は栄養やアルコールに注意。気力では味 方をつくること, 情報交換といらのは一緒に闘 おうといらのを自分の力で作ってしまうことだ と。Aさんのことでも後から気がついたことが あります。弟さんに連絡することを主治医から 勧められた日の夜に，Bに兄弟のことを自慢げ にうれしそらに話されていたらしいんです。後 で振り返ってみると，2，3 日は下痢や発熱の 症状の記録が少ないんです。おそらくその時は 症状が軽減していたと思われます。支える力を 得てほっとするとか, 気持が楽になるとか, そ ういう時には何か力がわいてきて免疫力が高まっ ているのではないかと思うんですが。

柴野：おっしゃるとおりだと思います。私がご 紹介した患者の場合にも，全身の浮腫で胸水も たまって呼吸もとても苦しい状態だったんです が，本当に最期をで私達が「苦しくない? 」 「どこか辛くない? 」と聞いても，返ってくる 言葉がいつも「大丈夫」だったんです。

精神的なところで支える人があったり，その 人にがんばろらといら気持があれば，身体的な 苦痛はすごく頑張れるということを学びました。 逆に身体的な苦痛が非常に強くなった時に，患 者さんの側のがんばろらといら気持がなくなっ てしまらこともいくつか経験しました。最期ま でがんばろらといら気持を持ち続けられる援助 が看護婦に求められているのだと思います。

和泉: そこの援助のところに関して。お 2 人と も今日出された事例は家族の援助が非常にいい かたちで行われたケースだったが，家族がどう 患者に関わるか，もしくは看護婦としてどうやっ て家族をサポートしていくかは，すごく難しい 問題だと思う。
私の発表では，アメリカでのエイズ看護のい い面とか，きれいな面を話したが，実際には社 会的教育が広まってきているとは言っても， まだまだ家族が自分の夫がホモセクシュアルだっ たとは信じられないとか, 最初に診断名を言わ れた時に家族が動摇してしまらことも多くて, そういう時の関わりがすごく難しかった。そう いう時に，どう家族へ介入されたのか。

柴野：いくつかの症例があります。

外国と日本の家族のあり方が違うせいなのか よくわかりませんが，入院患者達の最期を看と るのは家族です。ある男の患者の場合，お姉さ ん 3 人と両親の 5 人で亡くなられるまで毎日昼 と夜の食事介助に来られた。昼は私達がやりま すと言っても，看護婦さんだと甘えて食べない から私達が来ます，ということで欠かさず毎日 介助に来られたり, 感染に対する不安も感染経 路をきちっと括しすれば，それで割とすんな りと受けとめて, 患者の食事を介助しながらこ ぼれた物を自然に自分の口に入れたり。

夫婦の例では, 夫の感染, しかもホモセクシュ アルといらことがわかったことで, 最初は離婚 したいとか，すごく泣かれたりとか，面会の度 に奥さんのケアをしなければ，といらケースで も, じっくりと話を聞いて接して, 最期は亡く なられる 2 日位前から奥さんがずっと付き添っ て下さったり。

あるいは今も 1 組, 夫がホモセクシュアルか どらかはわからないが感染されて, 奥さんは性 的なことでの感染を疑いながらも，自分ももし かしたら感染しているのかもしれないけれども， 今もし自分の感染を知ったら夫をサポートでき ないから，私は今元気だし感染経路だけを知っ ていればいい，とご主人をサポートされている とか，…多くの家族の人達が患者を支えてい るのが実態じゃないかなと思います。

司会：会場の方からのご質問をどらぞ。

$A$ : 和泉さんに。アメリカではエイズ検査を受 けるといら段階から，ケースワーカーがもし陽 性だったら，といらサポートをした上で検査す ると聞いた。アメリカでのケースワーカーと看 護婦との役割分担についてお聞きしたい。柴野 さんに。マネージメントは誰がするのが適切だ 


\section{と考えるか (大阪日赤・高井)}

和泉：ケースワーカーがどこの時点で関わって くるかは，施設とか州によっても変わってくる と思う。八ワイでは, 地元の健康センターに血 液検査を受けに来た場合は，検査を受ける前に 一通りの説明をし，その時点で検査を受けるか 受けないかを本人に選択させる。選択させるこ と自体がエイズの教育と考劣られていたので, ケースワーカーが関わっているように思った。

私の㗢いていたホスピスでは, 予後が 6 力月 以内と診断された方が入って来るので, 血液検 查の時点でケースワーカーもしくは看護婦がど ら関与していたかはわからない。1人の患者を ケースワーカー, 看護婦, ボランティア, 医師 それぞれが自分の気がついた点を言い合って， チーム全体で見ていくといらかたちでしていま した。

柴野: 私のところでも看護婦が全体のマネージ メントをしていく必要があると強く感じていま す。ドクターの場合, 告知して大変だからカウ ンセリングを，となる。

患者と長く接していて，その方がどういう援 助を望んでいるのかを知っている看護婦が, 全 体をマネージメントしていくことが非常に大事 だと思っています。

ただ，身体的なケアの確立が非常に遅れてい ると痛感しています。エイズ患者の場合, 正常 な免疫機能があれば問題とならない，一緒に共 存できるような微生物で次々と感染を繰り返す という，エイズ特有のいろんな感染症や脳症な どもあります。

看護婦は専門職として身体的なケアでまず役 割を果たすことが大事だと思っています。

司会：あるエイズ患者が, 私にとって 1 番大切 なのは気力だ。第 2 は食事療法, 第 3 はマッサー ジ, 第 4 は漢方薬, 第 5 に治療薬といわれた。 これらは看護婦の力が求められていることです 小。

それからもら 1 つ。エイズ患者の手記を読む と, 陽性と言われた時に汪とんどの方が自殺を 考学ていて，克服できるまで 3 か月もかかると。 抗体検査を受ける患者の問題について, 阿部さ んからお願いします。
阿部：耳鼻科の病棟に口内炎のひどい 30 代後半 の男性患者が入院し，医師がエイズの疑いがあ るので一応検査をと本人に伝え, 了承されて検 査された例があります。結果は陰性でしたが, その患者が退院される時に一言,「僕は陽性か もしれないといらことで検査を受けたが, 看護 婦さんは僕が検査を受けてから何ら態度が変わ らなかった」といわれたといらことです。この 病棟にエイズ患者が入ってきても看護できそう だすすてきな評価をいただいたと思いました。 検査結果がでるまで患者は陽性か陰性かわから ない状態でいるわけですが，神経は敏感になり， 周囲の人がどのような態度を自分に示すかと, 1 人 1 人をよく見ていると感じました。

柴野 : 看護婦の問題ももちろんありますが，医 者や病院の体制も非常に問題があると思います。

1つだけ例をあげてお話をします。私のプラ イマリーの患者ですが，この方は日本人ですが 5 歳の時に移民されて日本語よりもその国の言 葉の方が達者で, 日本語は片言程度でした。今 年の 4 月に出稼ぎで日本にきて 8 月に髄膜炎と わかり, ある地方で入院されました。䯣膜炎が なかなか治らないので, 了解をとらずにHIV抗 体検査をして陽性とわかった。

そのことを本人ではなく雇い主にだけ伝え， 紹介状を持たせて駒込病院に行きなさいと。す ぐ退院させられ, 夜中ずっと高速道路を走って らちの病院に到着したのは朝の 5 時。その方に は無断で検査をしたとは言えなくて，あらため て髄膜炎が治らないのは何か免疫機能に問題が あるんではないか, 免疫機能が落ちる例えば悪 性リンパ腫とかエイズとかそういう検査を全部 しましょうということで検査の了解をとって検 査をしました。結果は陽性でした。検査の結果 は即刻本人に告げました。

本人は前に入院していた病院で 1 か月も入院 していて, 血液を何回も取られて検査を受けた けれどもエイズだとは言われなかった, 駒込病 院の検査の仕方が間違っているんではないか, 前の病院に問い合わせて欲しいなど, HIV陽性 といらことを受け入れるのに普通の人以上に苦 しまれました。

他にもそらいう例がいくつかあるんです。看 
護婦が拒否するという問題じゃなくて, 病院と して体制をつくっていくといらところで, 是非 皆さんに発言していただきたいと思います。

司会：らい患者は, 社会防衛的な発想で隔離さ れた歷史をもっていますが，HIVやエイズ患者 の問題が， 1 人の人間よりも社会的な予防策の 方が大切だといら発想で行政的に運ばれると，

一体その人達がどらいら気持で生きているのか を察しながら支觉るこができるのはナースし かいなくなると思います。ここで，私が激しく 心を動かされたあるHIV陽性者の言葉を読み上 げてみます。

「いちいち説明して相手がどんな気持になるん だろらと表情を見ているだけでらんざり。面倒 臭いと自分で痛む歯を抜いた」。

歯が痛い時に歯医者に行けないのです。HIV 陽性と言うとみな断られる。仕方がないから言 わないで治療を受けたら，血液に対するまとも な対応ではなくて，これでは医療者に感染させ てしまう，と患者が心配しているのです。その 患者は10本自分で抜いたそうです。こういう状 態に今日本のHIV陽性者が置かれているといら ことです。

阿部：柴野さんは主任さんなので, 何か若いス タッフを見て，もっとこうであればとか，こん なことで困っているといらことがありますか。

柴野: 去年の卒業生は全員がエイズの患者の看 護をしたいといらことで入職した方なんです。 実はだいぶ前なんですけれども，ある若い看護 婦がエイズ患者の清拭をしていましたら，その 患者が「今日は忙しいの?」と聞かれたそらな んです。彼女は特に忙しい日ではなかったので 「いえ，ぞうしてですか」と聞いたら「いやあ， 随分拭き方が雑だから」と言われた。自分はそ んなに特別に雑にやったつもりはないと。

一般の患者と看護婦の関係では，そらいう言 葉はお腹の中で思っていてもなかなか出てこな いですよね。それを割とはっきりいう方もいる。 その時にその方が本当に言いたかったことは， 拭き方が雑だということなのか，どらいう気持 でそう言ったのだろらかとか, 看護場面を一緒 に検討しながらその人が本当に言いたかったこ とは何なのかと受けとめられるようになってい
きたいと思いながら若い人とは接しています。 司会：死とか感染とかの共通項だけでは捉えき れない特殊性があるように思いますね。がんの 患者さんですと，自分の苦しみをわかってもら いたい，わかってくれないというような訴えが まま聞かれますが，エイズの患者にはそれがな いようにも思らのですが，柴野さん，大勢見て いらっしゃってどうですか。

柴野 : そらですね。今のところ女性よりも男性 の方が多いんですが，感染に対する受けとめ方 も，性交渉で感染した方達は，自分がやったこ とで感染したのだからみたいな受けとめが強く て，日本の男性の特徵なのか，いろんなことを 要求したり主張したりするのではなくて，自分 の中で耐えてがんばってしまら方が多いような 気がしますけれども。

和泉：アメリカでは感染した男性かららつされ た女性の感染者が増えてきています。ある患者 は, HIV陽性でまだ発症はしていない段階でご 主人かららつされたことがわかり，ものすごく 怒って「自分が苦しんでいるのに何故その苦し みを私に与えたのか。同じ病気で苦しんでいる はずなのに，私にこんな苦しみを与えた旦那が 何故私のこの苦しみをわかってくれないのか」 と責めたといわれ，身内から感染した場合には， 自分の痛みを表出するといらことも見られると 思います。ただその女性の場合はご主人が亡く なってから，今度はその怒りをパワーに変えて， エイズ患者をサポートするグループの中でボラ ンティア活動とか，エイズ患者への理解を深め るための教育活動に積極的に参加されて, 自分 の生さ方を充実させようとされていました。

司会：誰にも知られたくないと思っていながら， 医師あるいは看護婦に知ってもらえた時の安堵 感をしみじみと書いたものが発表されていまし た。看護婦が何ができるのかという発想だけで は不十分ではないかと思います。

B : 柴野さんか阿部さんに。患者も悩みを出し ながら免疫力を高めるための看護をされていた ら教えていただきたい。それに向かって考えて いることがあればお願いしたい。（藤沢市立看 護専門学校・佐鹿）

柴野 : 先程の告知をされずに検査をされた患者 
は，外国から出稼ぎに来ていて，2 年くらいお 金を貯めて国に帰り，ビデオショップを開きた いといら夢をもっていました。髄膜炎が軽快し て，ケースワーカーと看護婦とドクターとブラ ジルに帰るかどらかのカンファレンスを何回も もちをした。

彼は日本で働き，お金を持ってブラジルに帰 りたいといらのが 1 番やりたいことでした。で もいろいろ聞くと, 働くのがすごく好きでブラ ジルに帰ったら仕事がないと言う。

今一生懸命病院の中で階段の上がり下りをやっ たり自分でリハビリのプログラムを作ってやっ ています。体重もベスト体重に近くなってきて， 僕はやっぱり元気になってきた，仕事もできる はずとがんばっています。最終的に選択する時 には，ポルトガル語のボランティアの方に来て いただいて，彼に病状をきちっと伝えながら選 んでもららよらなケアを今やっています。

阿部：最近のテキストに, ドクターの役割とし てHIV感染者への指導項目が出ていました。そ れには(1)告知, (2)治療方針の説明, (3)発病を阻 止するためのアドバイス, (4)他の人に感染させ ないためにはどうすればよいかの説明，そして (5)が社会的義務の説明とあります。これは，自 分に何ができるかを考㝋てもらら，家族や友人 との関わり合いを考㝋てもらら, 感染者にしか できない役割がある事実を指摘するというふら なことだそらです。ドクターの指導項目の中に こういうところまで入っているということには 驚きました。看護婦はボヤボヤしていられない と思います。患者でマスコミに出ている方や手 記を書いている方は, 社会的にその立場での役 割意識で動いています。それはとても健康的な 状態だと思います。かと言って直接あなたには 感染者にしかできない役割があると言うわけに はいかないので難しいと思います。

和泉：生さがいとか心の支えといらところ以外 に, バランスのとれたいい食事をとる, 元気な 時につくり置きをしておいて, 疲れて何も食べ たくないよらな時でも簡単に口通りよく入るよ らなものを実際に指導したり, マッサージの指 導を患者の家に行って, 患者の楽になる部分を 広げたり，患者は皆よく勉強していて，例えば
漢方が効くと聞けば勉強して自分で煎じて飲ん だりもしているので, 看護婦が助言なり紹介を することによって免疫力を高めるといらケアも されていました。

C : 今回初めて実際にエイズ患者を看護されて いる生の声を聞く事ができた。そらいら意味で はこの学会は画期的だったと思う。ここにいる 方で何人くらいの方が実際エイズ患者に出会っ たことがあるか，ケアしたことがあるかを知り たい。（広島総合病院）

司会：エイズ患者と出会ったことのある方, 挙 手願います(約30名？)。ケアをなさったことの ある方(さっさの半数くらい)。

柴野さん，プライマリーナースが，受持のエ イズ患者を失った時の休㗇の話題を。

柴野: つい先日, イギリスからエイズ病棟の婦 長さんが病院を見学されて, 私達ともディスカッ ションする時間がありました。その時にその婦 長さんが，プライマリーの患者が亡くなった時 には一律看護婦に 2 週間のお休みをあげていま すとおっしゃったんです。ららやましいといら 声があがったんですが，私は「イギリスの看護 婦さん達患者が亡くなられた後には 2 週間く らい休みをとらないと次の患者のケアができな いという，そらいら深い関わりをしていらっしゃ る。私達も 2 週間の休みが必要になるよらなケ アをみんなでやりましょら」という話を後でし たんです。まだ看護婦が果たさないといけない 役割がやっとでき始めたところですから，これ からそらいらケアを目指していきたいなと思っ ています。

司会:そこまでの関わりをしているか？といら 呟きを耳にしまして，楽しみにとっておきまし たが，スタッフとそらいう話し合いができる場 といらのは, 優れた看護が展開されているのだ ろらと思います。是非事例検討をされて私共も 共有できるようにしてください。

D：柴野さんに。看護婦がもっと社会的に発言 をしていくべきだといらことで，具体的にどん なららに伝えていったらいいか。(国立横須賀 病院付属看護学校・杉本)

司会：それは最後にお答えいただきます。今日 は, 実際の看護の優れたところをどのくらい引 
き出せるかが私の課題でした。皆様, 学びにな りましたでしょらか。私はこのシンポジウムの おかげで大変たくさんの事を学びました。そし て，知れば知るほど知らなかったことの重大さ を思い知らされています。私達はやはり知らな ければいけません。

これまでの歴史の中で, 医学も看護学も患者 が変えてきた。HIV陽性と判定された患者が自 殺を考光，立ち止ったのは家族が困るであろら といらこと，そしてその次に，HIV陽性の仲間 達のために自分は役立たねばならないといらこ と，そして最後に，自分が頑張ることで医師も 看護婦も変わってくれると患者達が期待してい るといらことを，私達は心深く刻み込んでおき たいと思います。

そらいう思いをこめて, 実際にエイズ患者を 看とられた方から最後に一言づつお願いしたい。 和泉: 今回このシンポジウムを通して，エイズ の看護がどこでも受けられるような体制を日本 にも作っていかなくてはいけないといらこと, それから，アメリカではHIVや感染症病棟を希 望する看護婦が多いらしいんですが，それは， HIVの看護が看護婦に対するチャレンジだと彼 女達はとらえていて，まだ治療法が確立されて ない分，看護婦ができる事がたくさんある，看 護婦が果たす役割は大きいと自信を持って頑張っ ています。それを見て日本の看護婦も負けじと， チャレンジ精神を旺盛に頑張らなければと思い ました。

阿部：少し長くなりますが，看護婦 Bのことを お話したいと思います。私は管理者ですが彼女 に 2 週間の休みをあげたかったと思います。彼 女は今主任として働いておりますが，このレポー 卜は, 彼女が「精一杯の生命に向き合う」と題 して院内の講習会で後輩達に話をした原稿なん です。彼女の許可をもらってまいりましたので， 読みたいと思います。

$\lceil … …$ 私の今までの人生の中で重大な事が起こっ た時に，Aさんが生き生きと甦ってきたのです。 心配していた結婚も 3 年前にできて去年私は妊 娠しました。母親となれる喜びを感じたのもつ かの間で, 妊娠の検診を受けた時の検査で, 私 は子宮頸部癌の診断を受けました。13週目に入っ
た時のことでした。子宮が胎児を育てる環境に 変わるので, 一緒に癌も育ってしまう, 胎児が 安定する時期に入ったら手術をした方がよいと。 先生の話を聞いた時に, とっさに手術を受ける ことは胎児の生育環境を整えるといらことなの だといらことは考えられたのですが，思いもよ らない病名を告げられた衝撃といらのはどらに もならないもので，その日 1 日は涙が流れて止 まりませんでした。私が取る栄養分が子供のた めに使われているのか, 癌細胞のために使われ ているのかなど，どらでもよいことを考えたり， 癌細胞なんかに負けるな，負けるなと心の中で 叫び続けながら過ごし， 1 週後14週に入った日 に入院となりました。入院することで, 病棟の スタッフに多大な影響を与えてしまうことを考 えると，とても心苦しいものでしたが，思い切っ て代理となるスタッフに入院することを話しま した。Aさんが弟さんに下痢で入院すると告げ て入院したのと同じですね。胎内環境を整える ための手術とは言っても，手術の侵襲は育まれ つつある小さな命には私が受ける以上に大きい ものです。本当にこの時期に手術を受けること がよいことなのかどうか，手術台に乗った時に もまだ考えていました。そんな時にらと，Aさ んが思い浮かんだのです。今にも途絶えそうな 命を自分で感じながら，生きると言った $\mathrm{A} さ ん ，$ そのAさんに私は何て言ったんだろう，私が今 この状況を乗り越えなければこの子は生さられ ないんだ，がんばろう，負けるんじゃないぞ， がんばれと心の中で話しかけていました。手術 も無事に終わり，さあ仕事に戻ってがんばらな きゃと思っていた矢先に，早産となるリスクは 高くなるのでできるだけ安静にと言うのです。 手術さえ終われば元に戻れると思っていたのに と，今度は違ら試練が私を襲ってきました。見 た目には健康そのものの私が，妊娠を継続する ために長期間休をなければならない，拈腹の子 どもも大事だけど, 仕事も大事, スタッフも大 事。どうにもならないジレンマに襲われ，子宮 収縮予防剤を増やしてもらって，しぶる先生に 復職の許可をもらいましたが, 復職 2 日目にし て出血, 主治医には病気の人を手助けする看護 婦さんが自分の子どもを殺してどらするんです 
か，とまで言われる始末でした。仕事に戻るの はスタッフのため? いや自分のためでした。 そんな時にまた，Aさんのことを思い出します。 周囲のことを考光て自殺することもできなかっ たAさん，社会に背を向けて生きていたようで, 実は共存できるように生き方を選択した Aさん だった。私が今しなければいけない事は何だろ ら，拈腹の中の命を考光ることなのだろらか， そんな葛藤の日々がしばらく続きましたが，少 しずつせり出してきたお腹に初めて生命を感じ ました。あっ，私はまた自分の位置を動かずに， 自分の立場だけから物事を判断しようとしてい たなあ, この扮腹の中に生命があるのだ。そし て私はマタニティー雑誌ではなく,『育児の生 理学』や『驚異の小宇宙』の循環や免疫の章を 読んで, 命が生命へと変わる過程を想像し, 手 術によってつくった胎内環境をようやく整え始 めたのでした。すでに24週に入っていました。 そして37週に入って出産したのですから, 心身 共に安定した私の妊娠期間はたったの 13 週でし たが，何とか無事に育ち今日 1 歳を迎えます。

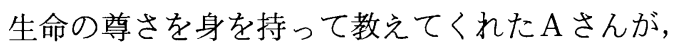
時折現れて私に問いかけをしてくれたのだ思 います。」

司会：ありがとうございました。言葉は何もい らないと思います。野々山さん，どらぞ。

野々山: 私は, 自分達が周りの人に風邪ひいた とか，喘息があるというのと同じくらい軽く， エイズなんだと言える社会をつくりたいと思い ます。看護婦, 助産婦, 保健婦は本当にパワー があると信じています。私達が，簡単にはらつ らないといら教育だけではなく, 私達は風邪の 患者や肺炎の患者と同じようにエイズの患者を 看ていると，身をもってみんなで示して欲しい。 そしてエイズを 1 つ病気と受け取ってもら光 るように発言もして欲しいし，その後ろ姿を見 せて欲しいと思っています。そうは言っても， 院長や病院の方針等もあって, 発言できないと ころもあると思います。頭では分かっていても やはり恐いという人もいると思います。私は病 院の中の看護を通してらつらないことを学びま したし，今地域でボランティアをやっていて， エイズ患者や感染者と一緒に食事をすることも
あります。そんな中でごく普通の人々だと私は 毎日感じています。皆さんもどんどん外に出て いろんな人に接していただきたい。そして，日 本を変えるために看護職が力を合わせていただ きたいと思っています。

もら 1 つは, 今接している感染者の方で, 名 乗り出た方は本当に強いです。それまではかな りの葛藤があっても, 名乗り出ると本当に強く, 世間のみんなにいろいろ㗢きかけをして, 私達 は学ぶ事ばかりです。でもそんな中でも何度も 悩んでいると言われています。そんな時，一生 懸命活躍している人達を支えようという動さを， 看護の人達が先頭に立って担っていって欲しい と思います。私もこれから一生懸命がんばって いきますので，皆さんもエイズの方を特別と思 わないでごく普通の自分の身近な 1 人と思って 支えてあげて欲しいと思います。㹉いします。

司会：柴野さん，ぞうぞお願いします。

柴野：それでは最後に，先皃ぞ質問むありまし たので，社会的な発言をどういうかたちでして いくかに絞って拈話をさせていただきます。こ れは諦めずにやるといらことが大事だと思って います。実は私が昨年 7 月に駒込に配属になっ た時には，こういらかたちで皆さんの前でエイ ズ患者の話をするのは，非常に困難でした。医 療現場自体が元々閉鎖的で，一般の社会から見 えない社会であるのに加えて，エイズ患者には プライバシーの保護の問題があって，余計に閉 鎖的になって外の人からは何も見光ない。エイ ズだけでなく医療者が患者のプライバシーを保 護することは大前提ですが，タブーを設けずに 発言することが大事だと思っています。

12月 9 日にNHKのニュースセブンといら番 組の中で, 駒込のエイズ看護の実態がほんの 5 , 6 分の短い番組ですが紹介されます。これまで の歷史をそのまま出しました。1人の感染者が 入浴ではらつらないと言われているのに, 私達 だけきれいな風呂を使わせてもらえないのはど らしてなのかといら括手紙を下さったんですが， その手紙も本人の了解を得て公表します。それ について私達が議論した経過も全部公表できる ことになりました。

テレビで報道された後, 一般の患者から私達 
はエイズ患者と一緒の風呂に入っているのかな どリアクションが来る可能性はあります。そう いらリアクションがあった時, そこで議論をす ればいいと。風呂ではらつらないといら指導も できる場にしていきたい。そらいらかたちでい ろんな事を諦めずにあるべき姿を発言していく といらことが 1 つ。

もら1つは先ほどお話した「日本HIV看護ネッ トワーク」ですが, 現在, 130名の会員がいらっ しゃいます。薄井先生も阿部婦長さんも会員で す。個人加盟の会で, 2 か月に 1 回の定例会と, 定例会のない月に事例検討をやろらということ で出発しています。興味のある方は是非参加し ていただきたい。この会がどれだけのことがで
きるのかはこれからですが，是非皆さんと一緒 にエイズの問題を考え, 必要な発言をしていき たいと思っています。今日はどうもありがとう ございました。

司会：どうもありがとうございました。今，エ イズ患者さんは, 共に生きる社会を目指して, 先頭に立って闘っていらっしゃいます。共に生 きる社会ができることが感染予防の最短距離だ といらことは，もら常識になりましたでしょう か。是非それを常識にする渦を広げていってい ただきたいと思います。今日はどうもありがと らございました。以上で終わらせていただきま す。 